\title{
Granulomatous involvement of the liver in patients with AIDS
}

\author{
M S ORENSTEIN, A TAVITIAN, B YONK, H P DINCSOY, J ZEREGA, \\ $S$ K IYER, AND E W STRAUS \\ From the Division of Digestive Diseases, Department of Medicine and Department of Pathology, State \\ University of New York-Downstate Medical Center, Brooklyn, New York
}

SUMmaRY During a one month period liver biopsy was carried out on eight patients with established acquired immune deficiency syndrome (AIDS) and two suspected of having AIDS to evaluate raised liver enzymes or unexplained fever and weight loss. Each of the 10 patients were found to have hepatic granulomas. Appropriate staining techniques showed acid-fast bacilli in seven of the liver specimens. One specimen contained numerous Cryptococcal organisms. Two biopsies showed granulomas but no organisms. Liver biopsy was found to be a high yield and rapid diagnostic procedure in patients with AIDS. Our results suggest that hepatic mycobacterial infection may be more common in the syndrome than previously recognised and that liver biopsy specimens should be examined routinely for the presence of acid-fast bacilli.

The acquired immune deficiency syndrome (AIDS) is characterised by the development of multiple opportunistic infections in a patient with no recognised cause of immunosuppression. The central nervous system, lung, and gastrointestinal tract, have been the most frequent organs noted to be involved by a wide range of infectious agents. ${ }^{1}$

Little has been published regarding hepatic involvement in patients with AIDS. A paucity of granulomatous response, lacking both caseation and multinucleated giant cells, with poorly formed granulomas and clusters of organisms within Kupffer cells was reported in the liver of a patient with AIDS who subsequently had mycobacterium aviumintracellulare cultured from bone marrow, liver, and urine. ${ }^{2}$ Other authors have noted infection by $M$ tuberculosis in patients with AIDS, but did not comment on liver histopathology. ${ }^{34}$

The present report suggests that involvement of the liver with mycobacterial disease may be a frequent feature of AIDS.

\section{Methods}

\section{PATIENTS}

During a one-month period liver biopsy was carried out on seven male and one female patient each of

Address for correspondence: Dr Eugene Straus, SUNY-Downstate Medical Center, 450 Clarkson Avenue, Box 1196, Brooklyn, New York, 11203, USA. Received for publication 1 February 1985 whom had an established diagnosis of AIDS by Centers for Disease Control (CDC) criteria as follows: a disease such as Pneumocystis carinii pneumonia or Kaposi's sarcoma that is at least moderately predictive of a defect in cell mediated immunity in a person with no obvious reason for diminished resistance to that disease. ${ }^{5}$ One male and one female patient having a syndrome consistent with the AIDS prodrome were also biopsied.

The patients ranged in age from 23 to 40 years. Nine were intravenous drug abusers and all denied homosexual relations. One (no 10) had immigrated from Haiti within nine months of admission. All were hospitalised at Downstate Medical Center and liver biopsies were undertaken because of raised circulating hepatic enzymes or prolonged unexplained fever and weight loss. All of the patients were febrile and cachectic.

Previously documented opportunistic infections included Pneumocystis carinii pneumonia in six patients, nasolabial or perirectal herpes for more than five weeks in three patients, cytomegalovirus infection in two patients, and oral or oesophageal candidiasis in nine patients. One patient had chronic mucocutaneous candidiasis for over two years and also had a 25-pound weight loss with prolonged fever and diarrhoea.

Mycobacterial pulmonary infection had been proven in six patients. Four patients had bronchial 
washings or lung biopsy tissue showing acid fast bacilli, $M$ tuberculosis was subsequently cultured from this material. One patient had $M$ aviumintracellulare cultured on repeated sputum samples. One patient had sputum smears positive for acid fast bacilli and a bone marrow biopsy which cultured $M$ avium-intracellulare. Results of these cultures were not known before liver biopsy.

All patients had normal prothrombin times. Liver biopsy was done with a 17 -gauge Jamshidi needle as previously described. ${ }^{6}$ The liver biopsy specimens were fixed in formalin, embedded in paraffin, and serially sectioned and stained with hematoxylineosin, periodic acid-Schiff and Gomori's methenamine silver methods for fungi and Ziehl-Nielsen method for acid fast bacilli. A sample of hepatic tissue was sent for mycobacterial and fungal cultures.

\section{Results}

The Table contains the clinical features and the results of liver biopsies in 10 patients with AIDS seen during a one month period. Eight of 10 liver biopsy specimens showed multiple epithelioid granulomas and acid fast bacilli were seen in seven and were numerous in all but one (Figs. 1 and 2). One biopsy specimen contained numerous cryptococci in the parenchyma and portal tracts (Fig. 3). In the remaining two cases a single epithelioid granuloma and one fibrotic nodule compatible with a healed granuloma were found but no organisms were demonstrated.

Cultures of liver biopsy material were positive for mycobacteria in all cases where abundant mycobacteria were seen on Ziehl-Nielsen stained sections. $M$ tuberculosis was cultured from one specimen and $M$ avium-intracellulare was cultured from six specimens. One patient (no 3) was proved to have atypical mycobacterial infection by liver biopsy done within a month of a sputum showing growth of $M$ tuberculosis. Histopathology in patient no 1, whose liver cultured $M$ tuberculosis, revealed abundant clusters of acid fast organisms with scanty

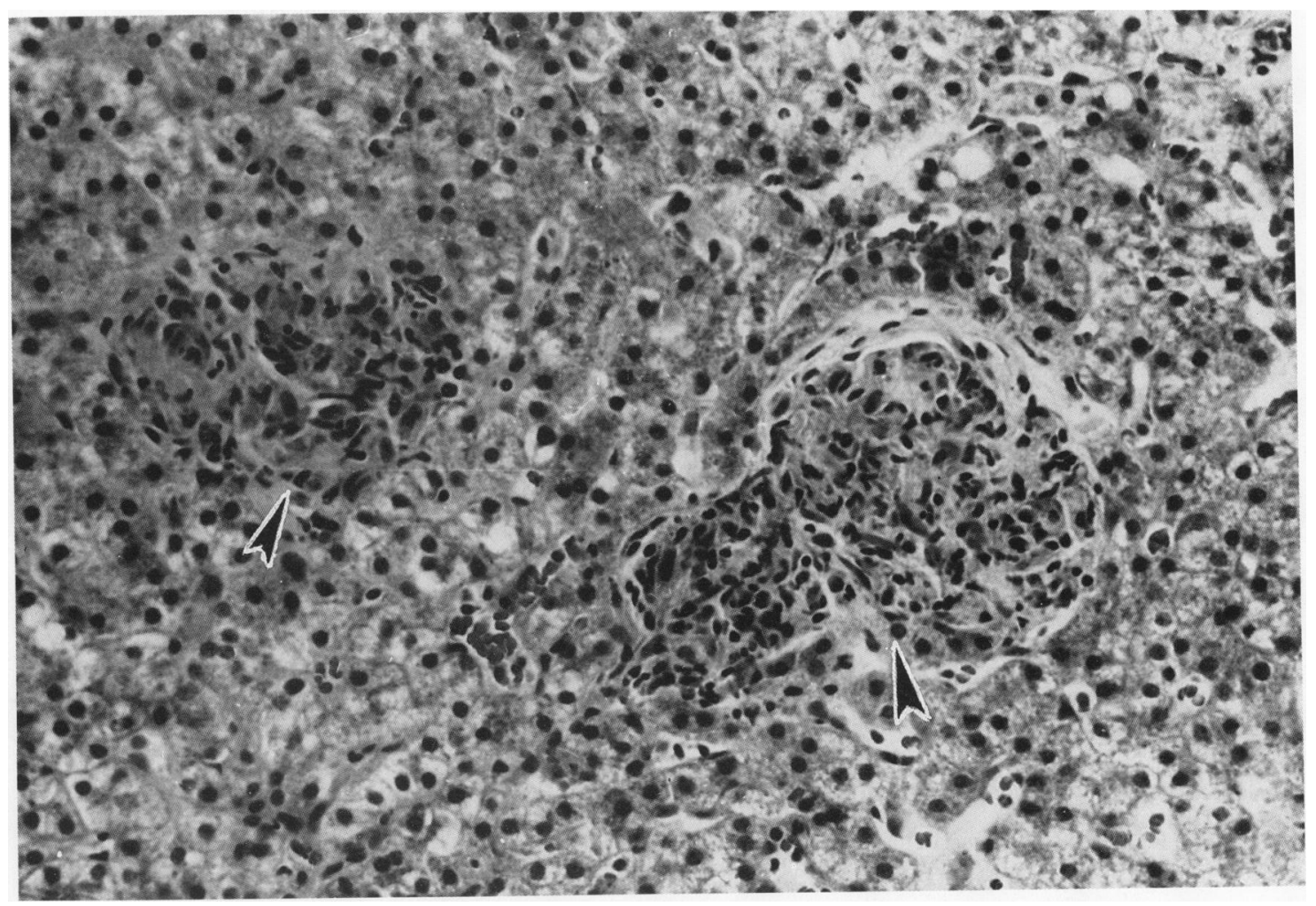

Fig. 1 Photomicrograph of liver biopsy from case 6 showing two microgranulomas (arrow heads). These granulomas are composed of epithelioid cells with no inflammatory infiltrate, giant cells or caseous necrosis ( $H \& E \times 160$, original magnification). 
Table Clinical, laboratory, and histologic features of 10 AIDS patients with granulomatous hepatitis

\begin{tabular}{|c|c|c|c|c|c|c|c|c|c|c|}
\hline & Sex & Age & $\begin{array}{l}\text { Opportunistic } \\
\text { infections* }\end{array}$ & $\begin{array}{l}\text { Prior mycobacterial } \\
\text { infections }\end{array}$ & Treatment $\dagger$ & $\begin{array}{l}\text { mU/M } \\
\text { Alk } \\
\text { Phos }\end{array}$ & $A S T$ & $A L T$ & Liver histology & $\begin{array}{l}\text { Liver culture for } \\
\text { AFB/fungus }\end{array}$ \\
\hline 1 & $\mathbf{M}$ & 23 & $\begin{array}{l}\text { P Carinii } \\
\text { (pneumonia) } \\
\text { Cytomegalovirus } \\
\text { Herpes (Naso } \\
\text { labial) Candidiasis } \\
\text { (Oral) }\end{array}$ & $\begin{array}{l}\text { M tuberculosis } \\
\text { (pulmonary) }\end{array}$ & $\begin{array}{l}\text { INH/RIF/EMB§ } \\
\text { SMX-TMP } \\
\text { Acyclovir }\end{array}$ & 320 & 48 & 65 & $\begin{array}{l}\text { Multiple } \\
\text { epithelioid } \\
\text { granulomas; } \\
\text { abundant AFB }\end{array}$ & $\begin{array}{l}(+) \mathrm{M} \\
\text { tuberculosis }\end{array}$ \\
\hline 2 & $\mathbf{F}$ & 28 & $\begin{array}{l}\text { Herpes Zoster } \\
\text { Herpes } \\
\text { (Nasolabial) } \\
\text { Candidiasis (Oral) }\end{array}$ & $\begin{array}{l}\text { M } \\
\text { avium-intracellulare } \\
\text { (pulmonary) }\end{array}$ & $\begin{array}{l}\text { INH/RIF/PZA/ } \\
\text { EMP } \\
\text { Ketoconazole }\end{array}$ & 215 & 26 & 15 & $\begin{array}{l}\text { Multiple indistinct } \\
\text { epithelioid } \\
\text { granulomas; } \\
\text { abundant } \\
\text { cryptococci }\end{array}$ & $(+)$ cryptococci \\
\hline 3 & $\mathbf{M}$ & 34 & $\begin{array}{l}\text { Herpes (Oral \& } \\
\text { perirectal) } \\
\text { Candidiasis (Oral) }\end{array}$ & $\begin{array}{l}\text { M tuberculosis } \\
\text { (pulmonary) }\end{array}$ & $\begin{array}{l}\text { INH/RIF/STREP } \\
\text { Acyclovir (Topical) }\end{array}$ & 234 & 79 & 39 & $\begin{array}{l}\text { Multiple } \\
\text { epithelioid } \\
\text { granulomas; } \\
\text { abundant AFB }\end{array}$ & $\begin{array}{l}\text { (+) M. avium- } \\
\text { intracellular }\end{array}$ \\
\hline 4 & $\mathbf{F}$ & 30 & $\begin{array}{l}\text { Candidiasis } \\
\text { (oesophageal) }\end{array}$ & $\begin{array}{l}\text { M tuberculosis } \\
\text { (pulmonary) }\end{array}$ & $\begin{array}{l}\text { INH/RIF/PZA } \\
\text { STREP/EMB }\end{array}$ & 923 & 109 & 43 & $\begin{array}{l}\text { Multiple } \\
\text { necrotising } \\
\text { epithelioid } \\
\text { granulomas; (-) } \\
\text { rare AFB }\end{array}$ & \\
\hline 5 & $\mathbf{M}$ & 32 & $\begin{array}{l}\text { P Carinii } \\
\text { (pneumonia) } \\
\text { Candidiasis (Oral) }\end{array}$ & No & $\begin{array}{l}\text { SMX-TMP } \\
\text { Ketoconazole } \\
\text { Aminophylline }\end{array}$ & 1075 & 123 & 50 & $\begin{array}{l}\text { Multiple } \\
\text { epithelioid } \\
\text { granulomas; } \\
\text { abundant AFB }\end{array}$ & $\begin{array}{l}\text { (+) M avium- } \\
\text { intracellular }\end{array}$ \\
\hline 6 & $\mathbf{M}$ & 33 & $\begin{array}{l}\text { P Carinii } \\
\text { (pneumonia) } \\
\text { Candidiasis } \\
\text { (oesophageal) } \\
\text { Cytomegalovirus } \\
\text { (oesophagitis) }\end{array}$ & No & $\begin{array}{l}\text { SMX-TMP } \\
\text { Hydrocortisone }\end{array}$ & 1004 & 39 & 54 & $\begin{array}{l}\text { Multiple } \\
\text { epithelioid } \\
\text { granulomas; } \\
\text { abundant AFB }\end{array}$ & $\begin{array}{l}\text { (+) M avium- } \\
\text { intracellular }\end{array}$ \\
\hline 7 & $\mathbf{M}$ & 24 & $\begin{array}{l}\text { P Carinii } \\
\text { (pneumonia) } \\
\text { Candidiasis (Oral) }\end{array}$ & & $\begin{array}{l}\text { Oxacillin } \\
\text { Nystatin }\end{array}$ & 74 & 237 & 351 & $\begin{array}{l}\text { Multiple } \\
\text { epithelioid } \\
\text { granulomas; few } \\
\text { AFB }\end{array}$ & $\begin{array}{l}\text { (+) M avium } \\
\text { intracellulare }\end{array}$ \\
\hline 8 & $\mathbf{M}$ & 23 & $\begin{array}{l}\text { Candidiasis } \\
\text { (chronic } \\
\text { mucocutaneous) }\end{array}$ & & $\begin{array}{l}\text { Nystatin } \\
\text { Gent./clotrimazole } \\
\text { Oxacillin } \\
\text { Ketoconazole }\end{array}$ & 89 & 34 & 17 & $\begin{array}{l}\text { One epithelioid } \\
\text { granuloma; no } \\
\text { AFB }\end{array}$ & $(-)$ \\
\hline 9 & $\mathbf{M}$ & 40 & $\begin{array}{l}\text { P Carinii } \\
\text { (pneumonia) } \\
\text { Candidiasis } \\
\text { (oesophageal) }\end{array}$ & $\begin{array}{l}\text { Mycobacteria } \\
\text { (unclassified) } \\
\text { (pulmonary, \& } \\
\text { bone marrow) }\end{array}$ & $\begin{array}{l}\text { Ansamycin } \\
\text { Ampho-B } \\
\text { STREP/EMB/ } \\
\text { CYCLOSERNE }\end{array}$ & 427 & 234 & 27 & $\begin{array}{l}\text { Multiple indistinct } \\
\text { epithelioid } \\
\text { granulomas; } \\
\text { abundant AFB; } \\
\text { micronodular } \\
\text { cirrhosis }\end{array}$ & $\begin{array}{l}\text { (+) M avium- } \\
\text { intracellulare }\end{array}$ \\
\hline 10 & $\mathbf{M}$ & 25 & $\begin{array}{l}\text { P Carinii } \\
\text { (pneumonia) } \\
\text { Candidiasis } \\
\text { (Oral) }\end{array}$ & $\begin{array}{l}\text { M tuberculosis } \\
\text { (pulmonary) }\end{array}$ & $\begin{array}{l}\text { INH/RIF/EMB } \\
\text { STREP SMX-TMP }\end{array}$ & 298 & 74 & 475 & $\begin{array}{l}\text { One healed } \\
\text { granuloma No } \\
\text { AFB }\end{array}$ & $(-)$ \\
\hline
\end{tabular}

${ }^{*}$ Infections include all prior known opportunistic infections.

$\dagger$ Medications at time of biopsy.

$\ddagger$ Plasma enzyme concentrations at time of liver biopsy.

Normal ranges alk. phos. (35-135), AST (0-40), ALT (0-40).

AFB Acid fast bacilli.

\& Abbreviations for drugs: INH=Isoniazid, RIF = Rifampin, EMB =Ethambutol, Ampho-B=Amphotericin-B,

SMX-TMP=Sulfamethoxazole-Trimethoprim, PZA=Pyrazinamide. 


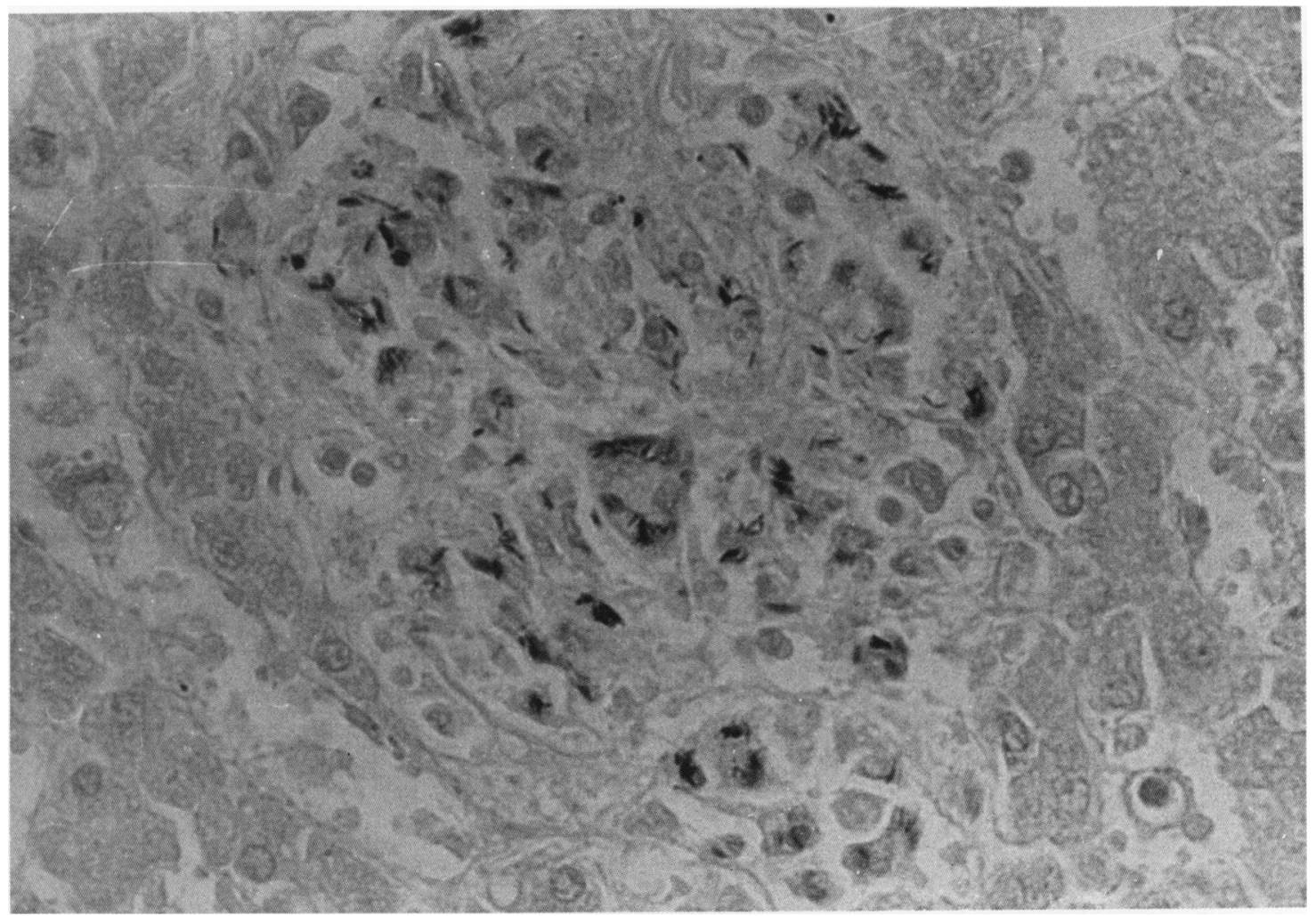

Fig. 2 Photomicrograph of a granuloma from case 6 showing abundant acid fast bacilli within the epithelioid cells. Culture of the liver tissue grew M avium-intracellulare. (Ziehl-Nielsen stain, $\times 400$, original magnification).

inflammatory response in a manner similar to that seen in the patients who cultured atypical mycobacteria from their liver biopsy specimens. The findings of non-caseating epithelioid granulomas (Fig. 1) or histiocytic clusters with abundant organisms seen within the cytoplasm of the histiocytes (Fig. 2) was therefore not unique to infections with mycobacterium avium-intracellulare (Fig. 3).

\section{Discussion}

The finding of unequivocal mycobacterial infection of the liver in seven of 10 consecutive patients suggests that this may be a more common feature of AIDS than is currently recognised. It should be noted that most of these patients were selected for liver biopsy on the basis of persistently raised alkaline phosphatase levels. The patients seen in this series included predominently intravenous drug abusers and no homosexual men were encountered. Whether the latter group is at such risk for mycobacterial infection can not be answered at present.
The histologic features in these cases varied from clusters of histiocytes to typical epithelioid granulomas, accompanied by very little inflammatory response and demonstrating abundant mycobacteria. It should be emphasised that mycobacterial infection may not be apparent on routine hematoxylin-eosin stained sections in some of these cases in which granulomatous inflammatory response is minimal. We therefore recommend that staining for acid-fast organisms be routine for the analysis of biopsy material from AIDS patients.

Disseminated tuberculosis has been described previously in patients with AIDS. ${ }^{2} 7$ Nonetheless, these diagnoses were established by lymph node, lung, or bone marrow biopsy. Liver biopsy was not reported. The appearance within tissue sections of abundant mycobacteria unaccompanied by significant inflammation simulates the histopathologic features of lepromatous leprosy. Mycobacteria are generally not seen in the liver biopsy specimens taken from immunocompetent patients with hepatic tuberculosis. ${ }^{8}$ Similarly, such specimens are most often culture negative. ${ }^{9}$ The frequency of culture 


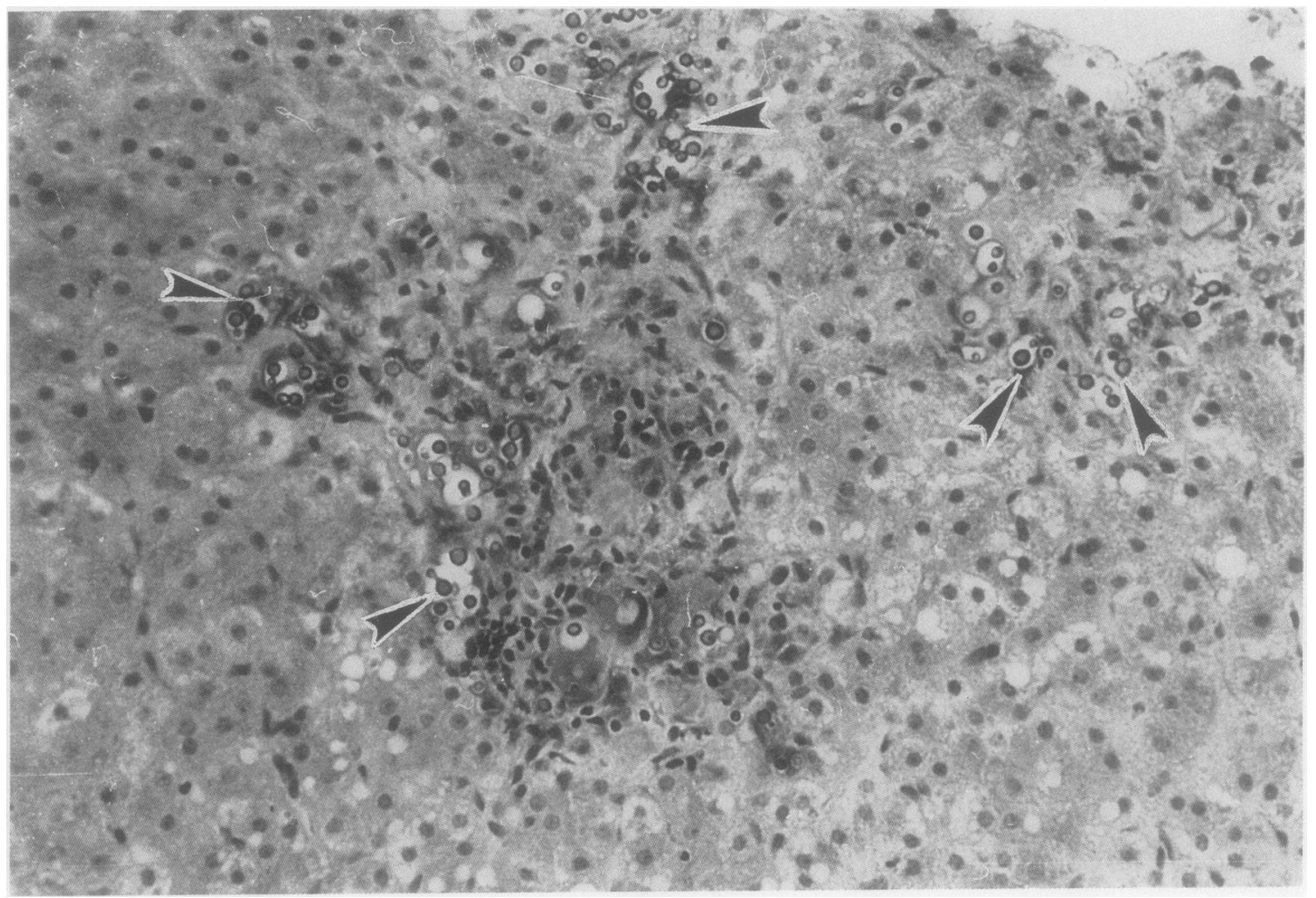

Fig. 3 Photomicrograph of liver biopsy from case 2 showing numerous cryptococci within the parenchyma (2 arrow heads) and a portal triad ( 3 arrow heads). (PAS stain, $\times 160$, original magnification).

positive liver biopsy specimens is an additional striking feature of this series and suggests that mycobacterial culture should be routine in the processing of liver tissue obtained from AIDS patients. In this regard it should be noted that one of our patients with previously established pulmonary infection with $M$ tuberculosis was found to have hepatic infection with $M$ avium-intracellulare.

It has recently been shown that mycobacterial antigens can induce in vitro suppression of lymphocyte responses. ${ }^{10} \mathrm{~A}$ central role for mycobacterial organisms in causing and perpetuating immunodeficiency has been reported in a patient who did not have AIDS. ${ }^{11}$ In this case $M$ fortuitum infection was associated with the activation of specific antigen-activated suppressor cells that compromised the phagocytic cell function of the patient. The bactericidal defect was reversed in vitro and in vivo by a cholinergic agonist combined with a prostaglandin synthetase inhibitor. These observations are particularly intriguing because they imply that concomitant mycobacterial infection might compound the immunologic deficiency that characterises AIDS.

\section{References}

1 Gottlieb MS, Groopman JE, Weinstein WM, Fahey $\mathrm{JL}$, Detels R. The acquired immunodeficiency syndrome. Ann Intern Med 1983; 99: 208-20.

2 Greene JB, Sidhu GS, Lawin S, Levine JF et al. Mycobacterium avium intracellulare: A cause of disseminated life threatening infection in homosexuals and drug abusers. Ann Intern Med 1982; 97: 539-46.

3 Vieira J, Frank E, Spira TJ, Landesman SH. Acquired immune deficiency in Haitians. N Engl J Med 1983; 309: 125-9.

4 Pitchenik AE, Fischl MA, Pickinson GM, Becker DM et al. Opportunistic infections and Kaposi's sarcoma among Haitians: Evidence of a new acquired immunodeficiency state. Ann Intern Med 1983; 98: 277-84.

5 Update on acquired immunodeficiency syndrome 
(AIDS) - United States. Morbid Mortal Weekly Rep 1982; 31: 507-8.

6 Menghini G. One-second biopsy of the liver. Gastroenterology 1958; 35: 190-9.

7 Fauci AS, Macher AM, Longo DL et al. Acquired immunodeficiency syndrome: epidemiologic, clinical, immunologic, and therapeutic considerations. Ann Intern Med 1984; 100: 92-106.

8 Korn RJ, Kellow WF, Heller P, Chomet B, Zimmerman HJ. Hepatic involvement in extra pulmonary tuberculosis: histologic and functional features. $\mathrm{Am} \mathrm{J}$ Med 1959; 27: 60-71.
9 Alvarez S, McCabe WR. Extrapulmonary tuberculosis revisited: a review of experience at Boston City and other hospitals. Medicine 1984; 63: 25-55.

10 Kleinhenz ME, Ellner JJ, Spagnuolo PJ, Daniel TM. Suppression of lymphocyte responses by tuberculous plasma and mycobacterial arabinogalactan. Monocyte dependence and indomethacin reversibility. $J$ Clin Invest 1981; 68: 153-62.

11 Gardner JD, Ousley M. Godfrey W, Lindsey N, Abdou N. Mycobacterium fortuitum infection: Evidence of bactericidal defect due to hyperactive antigenspecific suppressor cells. Am J Med 1982; 73: 756-64. 